\title{
Money Back Plan towards Life Insurance
}

\author{
M. Ajith, Gowtham Aasirvad, Prasath
}

\begin{abstract}
This project deals with the study about the need for the Life Insurance and to study about the Money Back Policies and its types. Terms and Conditions of the study. Advantages and Disadvantages of the study
\end{abstract}

Keywords : Royal Enfieldand, endeavor, unwaveringness

\section{INTRODUCTION}

Protection Regulatory and Development Authority (IRDA) requires all extra security organizations working in India to give official outlines to their clients. The representations depend on the speculation paces of return set by the Life Insurance Council (comprised under Section 64C(a) of the Insurance Act 1938) and isn't planned to mirror the genuine venture returns accomplished or might be accomplished in future by Life Insurance Corporation of India (LICI).

For the year 2004-05 the two paces of speculation return announced by the Life Insurance Council are 6\% and 10\% per annum.

Item rundown:

This is a Money Back sort Assurance plan that give budgetary security against death all through the term of plan alongside the intermittent installments on survival at indicated lengths during the term. [31],[33]

Revised Manuscript Received on July 22, 2019.

M.Ajith, Student,Department of MBA,Bharath institute of Higher Education \& Research,Tamilnadu,India Email:ajith88@gmail.com

Gowtham Aasirvad, Assistant Professor,Department of MBA,Bharath institute of Higher Education \& Research,Tamilnadu,India

Prasath Department of Biomedical Engineering, ,Bharath institute of Higher Education \& Research,Tamilnadu,India, Email: prasathaliassurendhars@yahoo.com

\section{METHODS OF DATA COLLECTION}

Accumulation of the information is fundamental piece of research. The idea of information which is gathered and utilized for this examination is auxiliary in nature. The significant and required information has been gathered from diaries, dailies, yearly reports, magazines, writing and sites of chosen organizations and through different web crawlers. [14],[ 16], [18]

\section{RESULTS \&DISCUSSION}

Information Envelopment Analysis (DEA) is a non-parametric straight programming apparatus by and large utilized for execution assessment of financial units through the development of a monetary boondocks. [8],[ 10] ,[12]It was initially produced for execution estimation. The upside of DEA is that it requires not many earlier suppositions on information yield relationship. [20],[ 22], [24] The DEA technique empowers expansion of the single information single yield specialized productivity measure to the numerous yield different info case. In its consistent comes back to scale structure, the DEA approach was created by Charnes, Cooper and Rhodes (1978). Financier, Charnes and Cooper (1984) stretched out the way to deal with the instance of variable comes back to scale. The DEA approach develops the generation wilderness from piecewise direct stretches bringing about an arched creation probability set. [1],[3],[5] The chief bit of leeway of the DEA approach comes from the way that the supposition of a particular utilitarian type of the fundamental innovation isn't important. This makes DEA especially helpful when managing administration ventures, since we have extremely constrained learning about the fundamental creation innovation in such cases. Rather than utilizing any practical structure, DEA utilizes direct programming ways to deal with envelope the watched information as firmly as could be expected under the circumstances. It just necessitates that the generation plausibility set is arched and the sources of info and yields are expendable. [2],[4],[6]

TABLE 1 : Medical Benefits Linked Insurance

\begin{tabular}{|l|l|l|l|l|}
\hline \multicolumn{5}{|c|}{ Medical Benefits Linked Insurance } \\
\hline & \multicolumn{2}{|c|}{ Rural } & \multicolumn{2}{c|}{ Urban } \\
\hline & $\begin{array}{l}\text { Frequenc } \\
\text { y }\end{array}$ & Percent & $\begin{array}{l}\text { Frequen } \\
\text { cy }\end{array}$ & Percent \\
\hline Yes & 38 & 7.6 & 82 & 16.4 \\
\hline No & 462 & 92.4 & 418 & 83.6 \\
\hline $\begin{array}{l}\text { Tota } \\
1\end{array}$ & 120 & 100.0 & 120 & 100.0 \\
\hline
\end{tabular}

Published By: Blue Eyes Intelligence Engineering \& Sciences Publication

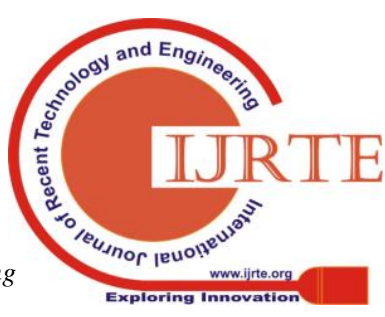




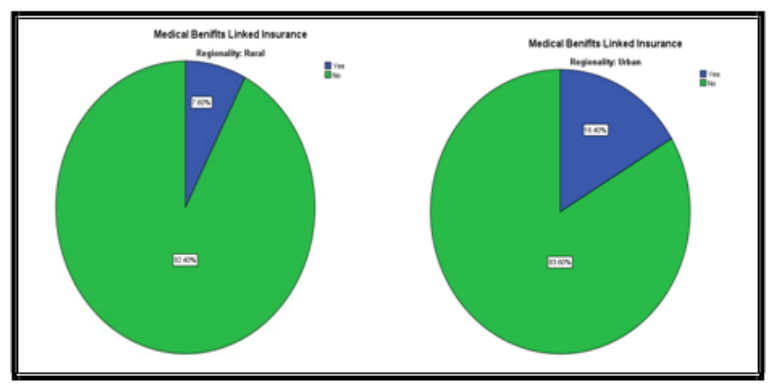

TABLE 2: Children Plan

\begin{tabular}{|l|l|l|l|l|}
\hline \multicolumn{5}{|c|}{ Children Plan } \\
\hline \\
\hline
\end{tabular}

TABLE 3: Joint Life Plan

\begin{tabular}{|c|l|l|l|l|}
\hline \multicolumn{5}{|c|}{ Joint Life Plan } \\
\hline & \multicolumn{2}{|c|}{ Rural } & \multicolumn{2}{c|}{ Urban } \\
\hline & Frequency & Percent & Frequency & Percent \\
\hline Yes & 61 & 12.2 & 91 & 18.2 \\
\hline No & 439 & 87.8 & 409 & 81.8 \\
\hline Total & 120 & 100.0 & 120 & 100.0 \\
\hline
\end{tabular}

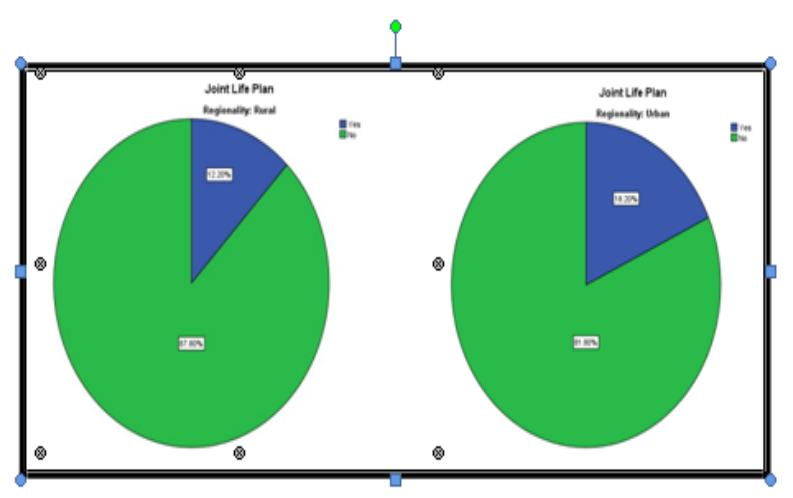

TABLE 4: CAPITAL MARKet Limited Plan

\begin{tabular}{|l|l|l|l|l|}
\hline \multicolumn{5}{|c|}{ Capital Market Limited Plan } \\
\hline & \multicolumn{2}{|c|}{ Rural } & \multicolumn{2}{c|}{ Urban } \\
\hline & Frequency & Percent & Frequency & Percent \\
\hline Yes & 18 & 3.6 & 6 & 1.2 \\
\hline No & 482 & 96.4 & 494 & 98.8 \\
\hline Total & 120 & 100.0 & 120 & 100.0 \\
\hline
\end{tabular}

Life coverage Company's are required to be fastidious with the hazard characterization as they manage open monies. [13], [15], , 17]The endorsing devices assume a significant job in setting the dangers proper. The fundamental dangers that are unexpected passing, handicap and are unreasonable life span. These dangers may destroy a person just as greetings/her wards monetarily by causing the stoppage of standard pay. Such a state is alluded to as "Financial Death" of a person. [7],[ 9],[11]

\section{REFERENCES}

1) BharthVajan R., Ramachandran S.,Psychographic dimensions of training,2016,International Journal of Pharmacy and Technology,V-8,I-4,P-23727-23729

2) Balakrishnan P., Bharthvajan R.,A study on human resource planning in hospitals in Chennai City,2014,International Journal of Applied Engineering Research,V-9,I-22,P-7503-7507

3) Priyadarsini P., Bharthvajan R.,Role of emotional intelligence training programme in reducing the stress of the nurses,2014,International Journal of Applied Engineering Research,V-9,I-22,P-7411-7421

4) Kerinab Beenu G., Bharthvajan R.,Empirical analysis on the cosmetic buying behavior of young women in South India,2014,International Journal of Applied Engineering Research,V-9,I-22,P-7361-7366

5) Balakrishnan P., Bharthvajan R.,Whistling in the wind,2014,International Journal of Applied Engineering Research, V-9,I-22,P-7586-7593

6) Krishnan B., Peter M.,Health hazards of Indian Bpo employee-an alarming issue,2014,International Journal of Applied Engineering Research,V-9,I-22,P-7336-7341

7) Kerinab Beenu G.H., Peter M.,Role of insurance in economic development,2014,International Journal of Applied Engineering Research,V-9,I-22,P-7532-7539

8) Balakrishnan P., Peter M., Priyadarsini P.,Efficiency of safety measures for wellbeing of employees in manufacturing industry,2014,International Journal of Applied Engineering Research,V-9,I-22,P-7376-7382

9) Anbarasi M., Praveen Kumar S.,Online sales promotions of herbal products and its effectiveness towards tanisha.com,2019,Indian Journal of Public Health Research and Development,V-10,I-1,P-195-200

10) Anbarasi M., Praveen Kumar S., Various online marketing and promotions strategies to improve the validation towards the organic products in the pharmaceutical sectors,2019,Indian Journal of Public Health Research and Development, V-10,I-1,P-263-269

11) Loganathan R., Praveen Kumar S.,Grievance handling a key factor for solving issues of employees in an organization,2014,International Journal of Applied Engineering Research,V-9,I-22,P-7483-7491

12) Loganathan R., Praveen Kumar S.,Study on preference of private label Engineering Research,V-9,I-22,P-7327-7335

13) Smitha M., Praveen Kumar S.,Understanding stress and its managementamong the nurses in Chennai city,2014,International Journal of Applied Engineering Research,V-9,I-22,P-7560-7565

14) Kerinab Beenu G.H., Praveen Kumar S.,A study on the investment behavior of Chennai investors in mutual fund schemes,2014,Internationa Journal of Applied Engineering Research,V-9,I-22,P-7520-7525

15) Loganathan R., Praveen Kumar S.,Retention strategies key for organizational productivity,2014,International Journal of Applied Engineering Research,V-9,I-22,P-7443-7447

16) Pavithra J., Ganesan M., Brindha G.,State wise analysis of microfinance sector in India,2016,International

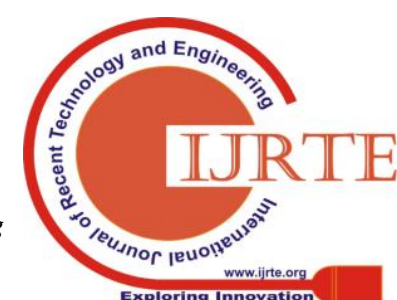


Journal of Pharmacy and Technology,V-8,I-4,P-23417-23432

17) Pavithra J., Ganesan M.,A comparative study on microfinance in India and abroad,2016,International Journal of Applied Business and Economic Research,V-14,I-8,P-5471-5476

18) Pavithra J., Ganesan M.,A study on awareness and impact of micro-financial schemes,2016,International Journal of Applied Business and Economic Research,V-14,I-8,P-5449-5460

19) Senthilmurugan P., Pavithra J.,Consumer preference towards organised retailing with reference to Big Bazaar,2014,International Journal of Applied Engineering Research,V-9,I-22,P-7469-7475

20) Senthilmurugan P., Pavithra J.,Implication of social media marketing in growing healthcare industry,2014,International Journal of Applied Engineering Research,V-9,I-22,P-7448-7456

21) Loganathan R., Pavithra J.,Consumer perception towards private label brand over other brands in super markets and hypermarkets,2014,International Journal of Applied Engineering Research,V-9,I-22,P-7355-7360

22) Kerinab Beenu G., Pavithra J.,Tradeâ€"off between liquidity and profitability in logistics industry,2014,International Journal of Applied Engineering Research,V-9,I-22,P-7398-7401

23) Kerinab Beenu G., Pavithra J.,A study on the prospective consumerâ€ $€^{\mathrm{TM}_{S}}$ perception towards utility cars in Chennai city,2014,International Journal of Applied Engineering Research,V-9,I-22,P-7526-7531

24) Pavithra J., Dilli Babu P., Ambuli T.V.,A study on budgetary control at Maruti Service Masters, Chennai,2014,International Journal of Applied Business and Economic Research,V-12,I-2,P-151-161

25) Pavithra J., Dilli Babu P., Ambuli T.V.,A study on customer satisfaction of retro Garments Pvt Ltd, Chennai,2014,International Journal of Applied Business and Economic Research,V-12,I-2,P-381-391

26) Kerinab Beenu G.H., Pavithra J., Senthilmurugan P.,A study on the influence of promotional activities for TATA ARIA among consumers in Chennai,2014,International Journal of Applied Engineering Research,V-9,I-22,P-7572-7578

27) Vijayaragavan S.P.,An investigative expert that's general FBG sensors,International Journal of Mechanical Engineering and Technology,V-8,I-8,PP-1500-1505,Y-2017

28) Vijayaragavan S.P.,Equalization routing protocol for $\mathrm{Wi}-\mathrm{Fi}$ sensor strategy,International Journal of Mechanical Engineering and Technology,V-8,I-8,PP-1662-1666,Y-2017

29) Karthik B., Kiran Kumar T.V.U., Vijayaragavan P., Bharath Kumaran E.,Design of a digital PLL using 0.35 $\hat{\mathrm{I}}^{1 / 4} \mathrm{~m}$ CMOS technology, Middle East Journal of Scientific Research,V-18,I-12,PP-1803-1806,Y-2013

30) Kanniga E., Selvaramarathnam K., Sundararajan M.,Kandigital bike operating system,Middle - East Journal of Scientific Research,V

31) Jasmin M., Vigneshwaran T., Beulah Hemalatha S.,Design of power aware on chip embedded memory based FSM encoding in FPGA,International Journal of Applied Engineering Research,V-10,I-2,PP-4487-4496,Y-2015

32) Jasmin M.,Optimization techniques for low power VLSI circuits,Middle East Journal of Scientific Research,V-20,I-9,PP-1082-1087,Y-2014

33) Jasmin M., Vigneswaran T.,Fuzzy controller for error control of on - Chip communication,2017 International Conference on Algorithms, Methodology, Models and Applications in Emerging Technologies, ICAMMAET 2017,V-2017-January,I-,PP-1-5,Y-2017

\section{AUTHORS PROFILE}

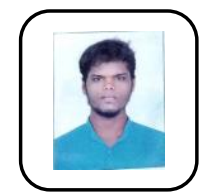

M.Ajith, Student,Department of MBA,Bharath institute of Higher Education \& Research,Tamilnadu,India

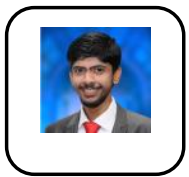

Gowtham Aasirvad, Assistant Professor,Department of MBA,Bharath institute of Higher Education \& Research,Tamilnadu,India

Prasath Department of Biomedical Engineering, ,Bharath institute of Higher Education \& Research,Tamilnadu,India 